\title{
Online Buying Behaviour: A Study With Reference To Nagercoil Town
}

\author{
D.Deekshith ${ }^{1}$, Dr. M.J.Deepa ${ }^{2}$, Dr. M.C.Shibin Tad \\ \{dichi28@gmail.com ${ }^{1}$, mjdeepa1@gmail.com ${ }^{2}$, shibintad@gmail.com ${ }^{3}$ \} \\ Research Scholar, Faculty of Management Studies, Noorul Islam Centre for Higher Education, \\ Kumaracoil ${ }^{1}$, \\ Assistant professor, Department of Business Administration, S.T.Hindu College, Nagercoil ${ }^{2}$ \\ Assistant professor, Faculty of Management Studies, Noorul Islam Centre for Higher \\ Education, Kumaracoil ${ }^{3}$
}

\begin{abstract}
The Trading in the contemporary world involves the use of the internet to provide a virtual sphere where merchants and buyers can engage in selling and purchases of goods, without even leaving their comfort zones.

The buyers and sellers can engage in trade from different parts of the world, from different time zones and they need not even speak the same languages. Online trading has evolved limitlessly during this era of globalization. The customers and vendors of this era are highly influenced by modern technology and at the same time, they are highly creative as well. Eventually, the internet has provided a platform to showcase their commercial creativity and showcase e-commerce as one of its primary offering. Ecommerce or online business offers services like -Bussiness, e-CRM, e-Supply chain, eMarketplace, e-Payment, e-Entertainment, e-Ticketing, e-learning, to e-Citizen and egovernance which were only available in the physical world in the past. Online shopping is eventually gaining shape as a well-acknowledged approach to buy and sell different products and services such as PC accessory items, automobiles, automobile spare parts, travel items, venture items, garments, blossoms, books, music, homes, and even real estates. Information for this study is gathered by distributing an organized questionnaire. This study intends to uncover the customer's conduct in purchasing, factors influencing purchasing, issues concerning the purchasing, relevant discoveries and proposals.
\end{abstract}

Keywords: Consumer buying behavior, online shopping, online customers.

Keywords: Bussiness, e-CRM, e-Supply chain, e-Marketplace, e-Entertainment, elearning.

\section{Introduction}

Online shopping is a developing technological advancement that offers vast varieties to buy and sell various products and services through the internet. It enables users to find the item for their requirements without even leaving their current location. This saves them a lot of time and effort. this practice can be executed by the users at any point of time during the day. E-commerce or Online shopping offered such a great convenience that this has become a part of everyday life for a normal person. In the beginning, the internet was just a model for 
correspondence and eventually, it has evolved into a medium that offers to learn, trade, enterprise and much more. Internet technologies have created another method of trade among purchasers and sellers and have created a customer-centric commercial center. Online shopping has become an alternative to the traditional form of trading. In comparison to conventional shopping, customers prefer web-based shopping primarily because of the convenience that it offers for its users. It provides its users with the option to be in their comfort zone and choose the required product by just entering the details of the products and choose from a wide collection of options and alternatives. Online shopping also provides really satisfying discounts which most of the users find it alluring. Also, some of the ecommerce giants are well known to offer seamless and punctual delivery procedures. Use of the internet for shopping has altered the shopping methods for many users. Online shoppers display a different buying behavior when compared to conventional forms of shopping.

\section{Statement of the problem:}

Internet-based purchases of products are considered as costly and inferior, are still common to a large extend presently. It is being accepted by the general public because of reconciliation, rapid exchanges, time sparing, attractive deals and offers and much more. online shopping is relatively a new concept and is in the developing phase, and there are no unshakable conventions presently.

\section{Objectives of the study:}

The objectives of the study are:

- To analyze the buying behavior of online shoppers

- To identify the problems faced by online buyers.

- To determine the internet usage profile of the respondents.

\section{Methodology:}

The following Methodology was used for conducting the present study.

Area of the study: The current study examines the online buying behavior of sample respondents selected from Nagercoil Town.

Data Source: The study is selected from among the internet users

Primary data: Obtained by distributing a well - structured questionnaire to respondents.

Sampling design: Non- random sampling for choosing the respondent.

Sampling size: A total of 25 respondents were used for the study, out of which 23 were internet shoppers. 
Secondary data: Secondary data was collected from different from books, research papers, reports, journals, published research work on online consumer behavior and websites.

Limitations and Scope for the study: Few limitations were identified in the course of study. It focused only a few internet shoppers. Limited variables were used. Future researchers can use different variables.

Literature Review:

There have been many comprehensive studies on online shopping attitudes and behavior in the recent past. For instance, Case et al (2001) suggested that internet know-how, income level, and education are powerful predictors of internet purchases among university students. Bellman and colleagues (1999) disclosed that the internet population is relatively younger, more educated and wealthier. although the gaps are eventually blurring.

\section{Analysis and Discussion:}

Internet usage profile of the respondents:

The internet usage profile of the respondents is shown in the following table.

Table 1: Internet usage profile of the Respondents

\begin{tabular}{|c|c|c|c|}
\hline Statements & Category & Number & percentage \\
\hline $\begin{array}{l}\text { No. of years since } \\
\text { using a computer }\end{array}$ & $\begin{array}{l}\text { Less than } 1 \text { yr } \\
1-4 y r s \\
4-6 \text { yrs } \\
6 y r s+\end{array}$ & $\begin{array}{l}6 \\
8 \\
6 \\
3\end{array}$ & $\begin{array}{l}26.1 \\
34.7 \\
26.2 \\
13.0\end{array}$ \\
\hline $\begin{array}{l}\text { No of years since } \\
\text { using the internet }\end{array}$ & $\begin{array}{l}\text { Less than } 1 \mathrm{yr} \\
1-4 \text { yrs } \\
4-6 y r s \\
4 y r s+\end{array}$ & $\begin{array}{l}4 \\
8 \\
2 \\
9\end{array}$ & $\begin{array}{l}17.4 \\
34.8 \\
8.7 \\
39.1 \\
\end{array}$ \\
\hline $\begin{array}{l}\text { Expertise in internet } \\
\text { surfing }\end{array}$ & $\begin{array}{l}\text { Beginner } \\
\text { Intermediate } \\
\text { Expert }\end{array}$ & $\begin{array}{l}3 \\
10 \\
10\end{array}$ & $\begin{array}{l}13.0 \\
43.5 \\
43.5\end{array}$ \\
\hline $\begin{array}{c}\text { Hours spent on } \\
\text { internet surfing per week }\end{array}$ & $\begin{array}{l}\text { Less than } 5 \mathrm{hrs} \\
5-10 \mathrm{hrs} \\
\text { More than } \\
\text { 10hrs }\end{array}$ & $\begin{array}{l}9 \\
6 \\
8\end{array}$ & $\begin{array}{l}39.1 \\
26.2 \\
34.7\end{array}$ \\
\hline $\begin{array}{l}\text { Place of using the } \\
\text { internet }\end{array}$ & $\begin{array}{l}\text { Home } \\
\text { Work place } \\
\text { Cyber/internet } \\
\text { café } \\
\text { Computer labs } \\
\text { On mobile } \\
\text { phone }\end{array}$ & $\begin{array}{l}7 \\
6 \\
5 \\
3 \\
2\end{array}$ & $\begin{array}{l}30.4 \\
26.2 \\
21.7 \\
13.0 \\
8.7\end{array}$ \\
\hline
\end{tabular}




\begin{tabular}{|c|l|l|l|}
\hline Concerned about & Not at all & 2 & 8.7 \\
internet security & Less concerned & 5 & 21.7 \\
& Neutral & 3 & 13.0 \\
& Concerned & 7 & 30.4 \\
& Quite concerned & 6 & 26.2 \\
\hline
\end{tabular}

Source: Primary data

Table 1 indicates that a higher portion of the respondents had been computer users for over six years.

Buying Behavior of online shoppers:

The buying behavior of the online shoppers is shown in the following table.

Table 2: Buying Behavior of Online Shoppers

\begin{tabular}{|c|l|l|l|}
\hline Statements & Category & Numbers & Percentage (\%) \\
\hline Online shopping & Frequent & 18 & 78.3 \\
frequency & Infrequent & 5 & 21.7 \\
\hline Information & $10-30$ mins & 20 & 87.0 \\
seeking & $30-60$ mins & 3 & 13.0 \\
\hline Decision making & Within a week & 2 & 9.0 \\
& After one week & 21 & 91.9 \\
\hline Online shopping & Recent shoppers & 6 & 26 \\
experience & Medium & 17 & 74 \\
\hline Amount spent & Low & 5 & 21.7 \\
& high & 18 & 78.3 \\
\hline
\end{tabular}

Source: Primary data

From Table 2 it can be understood that majority of the respondents are information seekers for 10-30mis (87\%), Under the decision-making stage, A majority (91.9\%) seeking information after one week, and $78.3 \%$ of the respondents spend amount.

Problems faced by online shoppers:

The following table reveals the problems of online shoppers.

Table 3: Problems of online shoppers

\begin{tabular}{|c|l|l|}
\hline Statements & Numbers & Percentage \\
\hline $\begin{array}{c}\text { Fake Messages about a } \\
\text { product }\end{array}$ & 10 & 43.5 \\
\hline $\begin{array}{c}\text { Low trust level of online } \\
\text { stores }\end{array}$ & 5 & 21.7 \\
\hline VAT/customs duty & 4 & 17.4 \\
\hline No refund policy & 4 & 17.4 \\
\hline
\end{tabular}

Source: Primary data

Table 3 indicates that majority of the respondents stated fake messages about a product as a major problem.

\section{Suggestions:}

- $\quad$ The marketers should completely avoid misleading advertisements. 
- The Government should adopt the necessary steps to provide high-speed internet access to the general public.

- To facilitate an opportunity to examine the product before the purchase.

- It is suggested that online vendors and e-commerce providers should adopt advanced technologies to maintain security for visitors online.

- Innovative services should be given to purchasers to contrasting the different items effectively and with making purchasing decisions.

- Excellent after-sales service should be provided to the buyers to offer them a fine experience.

- Majority of the Indian shoppers are used to conventional shopping methods. A majority of purchasers are used to buying temporary or seasonal products fro the internet. It is therefore suggested that the online vendor can focus on offering a large amount or wide variety of assured solid items.

- It is assumed that comfort and trust are the most important factors for customer satisfaction as well as decision making when shopping online, followed by the cost and nature of the products. These are considered as the most basic factors for any buyer to make a decision when shopping online.

- Online shopping seeks global parameters to ignore adjacent market standards. Concerning this statement, online vendors are required to acquire items conforming to the neighboring advertisement standards and become more viable for the local potential buyers. This will create better behavior for the buyers and help sellers to offer better deals for them.

\section{Conclusion}

E-commerce or E-retailing is probably one of the significant innovations that have influenced modern business to a large extent. It is contributing to a new economy, which has tremendous potential and in general sense, it is changing the future of many organizations. It is speculated that E-commerce will become a massive industry in the oncoming years and shopping is becoming an important aspect to meet their daily requirements of everyday lives effectively. Online shopping is evolving into a pattern of shopping methods. A number of buyers are enjoying the advantages that they have through online shopping. They cannot ignore the perks of online shopping like discounts, deals, $24 \times 7$ shopping, door to door delivery, choosing from a wide collection of products, having several alternatives to choose from, etc.

The principal reason which allure customers to online shopping is obviously the comfort and experience offered by the e-commerce vendors. Today, users can purchase railroads and air tickets, books, home appliances, electronic gadgets, movie tickets and much more by visiting a website. This study proposes that there is a rapid expansion in online shopping, and thus access to high-speed internet is very much required for the general public. Numerous purchasers and dealers across different socioeconomics are engaging in online shopping, as a result, it has impacted the lives of many people and bought unbiased changes. It is observed in the study that disregarding the immense potential outcomes available on the world wide web, it is still being used by people for surfing emailing and spending time. It is highly suggested to get the attention of such users as well so that internet commerce can be a dominant business model in the future. 


\section{References}

[1] Jayendra Sinha and Jiyeon Kim, "Factors affecting Indian consumers' online buying behavior", Innovative Marketing Review, Vol 8, Issue 2, 2012

[2] ChayapaKatawetawaraks and Cheng Lu Wang, "Online Shopper Behavior: Influences of Online Shopping Decision”, Asian Journal of Business Research, Vol 1, No 2, 2011

[3] Steven Bellman, Gerald L. Lohse, and Eric J. Johnson, "Predictors of Online Buying Behaviour", Communications of ACM, Vol 42, No 12, Dec 1999.

[4] Philip Kotler, Gary Armstrong, Prafulla Y. Agnihotri and Ehsan ulHaque, " Principles of Marketing", Pearson Education, Inc, Fifth Edition, 2013, pp no: 426-437

[5] Donald R Cooper, Pamela S Schindler and J K Sharma, "Business Research Methods", Tata McGraw Hill Education Private Limited, 11th Edition, 2012, , pp no: 528-536

[6] Saad Akbar and Paul T J James, "Consumer's attitudes towards Online Shopping: Factors influencing employees of crazy domains to shop online", Journal of Management and Marketing Research

[7] Rashed Al Karim, "Customer satisfaction in Online Shopping: a study into the reasons for motivations and inhibitions", IOSR Journal of Business and Management, vol 11, Issue 6, Aug 2013, pp 13-20

[8] Rayed AlGhamdi, Jeremy Nguyen, "Factors Influencing E-commerce adoption by retailers in Saudi Arabia: A Quantitative Analysis", International Journal of Electronic Commerce Studies, 2012, vol 3, No:1, pp no: 83-100.

[9] Dr.GagandeepNagra, Dr. R. Gopal, "A study on Factors affecting Online Shopping Behaviour of Consumers", International Journal of Scientific and Research Publications, June 2013 ,vol 3, Issue 6. 